\title{
Identification of a region responsible for binding to the cell wall within the S-layer protein of Clostridium thermocellum
}

\author{
Marc Lemaire, ${ }^{1}+$ Isabelle Miras, ${ }^{1}$ Pierre Gounon ${ }^{2}$ and Pierre Béguin ${ }^{1}$
}

Author for correspondence: Pierre Béguin. Tel: +331456888 19. Fax: +3314568 8790 . e-mail: beguin@pasteur.fr

Unité de Physiologie Cellulaire and URA 1300 CNRS, Département des Biotechnologies ${ }^{1}$ and Station de Microscopie Electronique ${ }^{2}$, Institut Pasteur, 28 rue du Dr Roux, 75724 Paris Cedex 15, France

\begin{abstract}
The protomer forming the S-layer of Clostridium thermocellum was identified as a $140 \mathrm{kDa}$ protein which was non-covalently bound to the cell wall. Cloning and sequencing of the corresponding gene revealed an open reading frame of 3108 nucleotides encoding a polypeptide of 1036 amino acids, termed SIpA. The amino acid composition of SIpA matches the composition of a previously described exocellular glycoprotein. SIpA shared extensive similarity with the Slayer protein of Bacillus sphaericus and with the outer wall protein of Bacillus brevis. In addition, the amino-terminal region of SIpA contained a segment presenting similarities with segments termed SLH (S-layer homologous), which are found in several bacterial exoproteins. A polypeptide of 209 residues comprising this segment was shown to bind to cell walls extracted from C. thermocellum cells.
\end{abstract}

Keywords: S-layer protein, Clostridium thermocellum, S-layer homologous (SLH) domain

\section{INTRODUCTION}

Clostridium thermocellum, a thermophilic, anaerobic bacterium, is best known for producing highly active multienzyme cellulase complexes termed cellulosomes (Johnson et al., 1982; Lamed et al., 1983). Electron micrographs show that the cytoplasmic membrane of $C$. thermocellum is surrounded by three layers: a relatively thin peptidoglycan layer, a regularly ordered S-layer, and an amorphous outer layer (Lamed \& Bayer, 1988; Nolte, 1992). Cellulosomes have been located in protuberances formed by the outer layer (Bayer \& Lamed, 1986; Bayer et al., 1985; Nolte \& Mayer, 1989). They are associated with a set of polypeptides thought to be responsible for the attachment of cellulosomes and individual cellulases to the surface of the cells (Fujino et al., 1993; Leibovitz \& Béguin, 1996; Salamitou et al., 1994a, b). These polypeptides contain a threefoldreiterated segment, termed the S-layer homologous (SLH) domain, which has been found in a number of Slayer proteins and in cell-bound exoenzymes degrading

†Present address: Département de Biochimie Médicale, Centre Médical Universitaire, 1 rue Michel Servet, $\mathrm{CH}-1211$ Geneva 4, Switzerland.

Abbreviation: SLH, S-layer homologous.

The GenBank accession number for the sequence reported in this paper is U79117. polysaccharides (Lupas et al., 1994; Matuschek et al., 1994). SLH domains appear to mediate attachment of proteins to the cell wall (Lemaire et al., 1995; Olabarría et al., 1996) as well as interactions with other SLH domains (Lemaire et al., 1995).

This prompted us to investigate whether SLH domains may also be involved in the interaction of the S-layer with the cell wall of C. thermocellum. This paper reports the identification of the protomer forming the $S$ layer of C. thermocellum, the demonstration that it is non-covalently bound to the cell wall, and the cloning and sequencing of the corresponding gene. A polypeptide derived from the amino-terminal region of the protein and harbouring a segment distantly related to SLH domains was found to bind to the C. thermocellum cell wall.

\section{METHODS}

Bacterial strains and culture conditions. C. thermocellum NCIMB 10682 was grown anaerobically with gentle stirring at $60^{\circ} \mathrm{C}$ in complete CM3-3 medium (Tailliez et al., 1989) containing $5 \mathrm{~g}$ cellobiose $\mathrm{I}^{-1}$ (Fluka AG). Escherichia coli strains TG1 (Gibson, 1984) and M15(pREP4) were used as cloning hosts and were grown at $37^{\circ} \mathrm{C}$ in $\mathrm{LB}$ medium (Maniatis et al., 1982). Ticarcillin $\left(100 \mu \mathrm{g} \mathrm{m}^{-1}\right)$ and kanamycin $\left(25 \mu \mathrm{g} \mathrm{ml}^{-1}\right)$ were added, depending on the plasmids present in the host. 
Preparation of Triton-X-100-treated cell envelopes of $C$. thermocellum. C. thermocellum cells from $50 \mathrm{ml}$ mid-exponential-phase cultures $\left(\mathrm{OD}_{600} 1-2\right.$; Beckman model $34 \mathrm{spec}$ trophotometer) were harvested by centrifugation, washed with $0 \cdot 15 \mathrm{M} \mathrm{NaCl}$, and resuspended in $5 \mathrm{ml} 50 \mathrm{mM}$ Tris $/ \mathrm{HCl}$ (pH 7.5) containing $150 \mathrm{mM} \mathrm{NaCl}$ (buffer A). Four millilitres of the suspension was disrupted by sonication, intact cells were removed by centrifuging twice for $5 \mathrm{~min}$ at $1900 \mathrm{~g}_{\max }$ and envelopes were pelleted by centrifuging for $20 \mathrm{~min}$ at $39000 \boldsymbol{g}_{\max }$. Triton-X-100-treated envelopes were prepared at room temperature by resuspending and centrifuging the pellet ( $20 \mathrm{~min}$ at $39000 \mathrm{~g}_{\max }$ ) successively in $1 \mathrm{ml} 1 \mathrm{M} \mathrm{NaCl}, 1 \mathrm{ml}$ buffer $\mathrm{A}$ and $1 \mathrm{ml}$ buffer A containing $1 \%(\mathrm{v} / \mathrm{v})$ Triton X-100. The final pellet was resuspended in $1 \mathrm{ml}$ buffer $A$.

Treatment of cell envelopes with lysozyme. Triton-X-100treated cell envelopes corresponding to $2 \mathrm{ml}$ original culture were incubated for $20 \mathrm{~min}$ at $37^{\circ} \mathrm{C}$ in $100 \mu \mathrm{l} 50 \mathrm{mM}$ Tris/ $\mathrm{HCl}$ (pH 7.5) containing or not containing $10 \mu \mathrm{g}$ lysozyme and centrifuged for $30 \mathrm{~min}$ at $20000 \mathrm{~g}$. The insoluble fraction was extracted by heating at $100^{\circ} \mathrm{C}$ with $100 \mu$ l sample buffer (Laemmli, 1970). Ten microlitres of the supernatant and of the insoluble fraction extracted by sample buffer were analysed by SDS-PAGE (Laemmli, 1970).

Electron microscopy of cell envelopes. Triton-X-100-treated cell envelopes were diluted $1: 100(\mathrm{v} / \mathrm{v})$ in $0 \cdot 1 \mathrm{M}$ ammonium acetate, $0.05 \mathrm{M}$ ammonium bicarbonate, $0.1 \mathrm{mM}$ EDTA ( $\mathrm{pH} \mathrm{7.2)} \mathrm{containing} \mathrm{6 \%} \mathrm{glycerol.} \mathrm{The} \mathrm{envelopes} \mathrm{were} \mathrm{mixed}$ thoroughly and spread over freshly cleaved mica. The samples were rotary-shadowed with platinum as previously described by Baccalà et al. (1991). Replicas were observed with a Philips CM12 electron microscope operating at $60 \mathrm{kV}$.

Sequencing of the amino-terminus and of internal peptides of the $\boldsymbol{C}$. thermocellum S-layer protein. For amino-terminal sequencing, cell envelopes containing approximately 5-10 $\mu \mathrm{g}$ S-layer protein were subjected to SDS-PAGE and transferred onto a hydrophobic PVDF membrane (Problott; Applied Biosystems) using the conditions recommended by the manufacturer. The $140 \mathrm{kDa}$ band was stained with $0.003 \%$ amido black (Aldrich) and cut out, and the amino-terminal sequence of the polypeptide was determined by the Edman method, using a model 473 A sequencer (Applied Biosystems). For sequencing internal peptides, $200 \mathrm{pmol}$ of the protein was loaded on an SDS-PAGE gel. The $140 \mathrm{kDa}$ band was cut out after staining with amido black and digested in situ with pig trypsin. Peptides were separated by $\mathrm{C}_{18}$ reverse-phase chromatography using a water/acetonitrile gradient in the presence of $0.1 \%$ trifluoroacetic acid. Two peptides having a high absorbance at $280 \mathrm{~nm}$ were sequenced as described above.

DNA manipulations. C. thermocellum genomic DNA was purified by the method of Quiviger et al. (1982). Other DNA manipulations were performed as described by Ausubel et al. (1990). Restriction enzymes were used as recommended by the suppliers.

Cloning and sequencing of the gene encoding the S-layer protein of $\mathbf{C}$. thermocellum. The degenerate oligonucleotide GAY GAT GAT GCI GTI GTI GAY GCI TGG GG, matching the internal peptide sequence DDDAVVDAWG, was labelled with $\left[\gamma{ }^{32} \mathrm{P}\right] \mathrm{ATP}$ and T4 polynucleotide kinase and used as a hybridization probe. Southern blots were performed on $C$. thermocellum DNA cut with various restriction enzymes, using increasingly stringent washing conditions. Upon washing blots twice for $30 \mathrm{~min}$ at $45^{\circ} \mathrm{C}$ with $1 \times \operatorname{SSC}(0.15 \mathrm{M}$ $\mathrm{NaCl} ; 0.015 \mathrm{M}$ sodium citrate), a major and a minor band were present in all digests. The $1.33 \mathrm{~kb}$ region of a HindIII digest of $C$. thermocellum genomic DNA corresponding to the stronger hybridizing HindIII fragment was extracted from an agarose gel and cloned into HindIII- and phosphatase-treated pTZ19R. One hundred and twenty cultures were started from independent recombinant colonies, and minipreparations of plasmid DNA were made from pools of three cultures each. Plasmid DNA was subjected to dot-blot hybridization, yielding one positive pool, from which one clone was isolated which contained a $1.33 \mathrm{~kb}$ DNA fragment encoding the previously sequenced oligopeptide. The remaining part of the sequence was obtained after cloning a $2.9 \mathrm{~kb}$ Pst I fragment bracketing the HindIII fragment, and a $0.85 \mathrm{~kb} H$ indIII fragment overlapping the latter (Fig. 4). DNA sequencing was performed on double-stranded templates using the Thermosequenase kit (Amersham) and synthetic oligonucleotides provided by Eurogentec or Genset.

Synthesis and purification of the SIpA $27-235$ polypeptide comprising the amino-terminal region of SlpA. The DNA segment encoding the region extending from codon 27 (beginning of the mature protein) to codon 235 of the coding sequence was amplified by PCR. Primers were TTT GCT GGA TCC GAT TCA TTC AGC TAT GAA AAA G and CAT CCA AAG CTT TTA CTT CCT TGA TGG CTT T, which provided BamHI and HindIII restriction sites flanking the $5^{\prime}$ and $3^{\prime}$ ends, respectively, of the fragment (Fig. 4). The amplified fragment was cloned into BamHI- and HindIIIdigested pQE-30 yielding pCT1923. In this construct, the coding sequence of the $\operatorname{sl} A A$ fragment is preceded by six His codons provided by the vector, enabling purification of the fusion polypeptide by $\mathrm{Ni}^{2+}$ affinity chromatography (Janknecht et al., 1991). The sequence of the insert was verified, and the plasmid was transferred to $E$. coli M15(pREP4) (Farabaugh, 1978; Villarejo \& Zabin, 1974) (Qiaexpress kit; Qiagen). A 11 culture of the resulting strain was grown to $\mathrm{OD}_{600} 0.5$ and induced overnight in the presence of $0.5 \mathrm{mM}$ IPTG. Cells were centrifuged and resuspended in $25 \mathrm{ml} 50 \mathrm{mM}$ Tris $/ \mathrm{HCl}(\mathrm{pH} 7.5)$ and disrupted in an Aminco French pressure cell at $100 \mathrm{MPa}$. The extract was centrifuged for $20 \mathrm{~min}$ at $25000 \mathrm{~g}$, and the cleared supernatant was loaded on an $8 \mathrm{ml} \mathrm{Ni}{ }^{2+}$-nitrilotriacetic column (Qiagen) equilibrated with $50 \mathrm{mM}$ Tris $/ \mathrm{HCl}(\mathrm{pH} 7 \cdot 5)$. The column was washed with the same buffer and eluted with the same buffer containing $250 \mathrm{mM}$ imidazole. The eluted fractions were pooled and dialysed against $50 \mathrm{mM}$ Tris $/ \mathrm{HCl}(\mathrm{pH} 7 \cdot 5)$. The final yield of purified polypeptide was $48 \mathrm{mg}$ (l culture $)^{-1}$.

Interaction of the SlpA $\mathrm{A}_{27-235}$ polypeptide with the cell wall of C. thermocellum. C. thermocellum cell walls were obtained after washing cell envelopes in the presence of boiling SDS, and binding experiments were performed by incubating and co-sedimenting the $\mathrm{SlpA}_{27-235}$ polypeptide with the cell wall (Lemaire et al., 1995). Amino acid and glucosamine analysis of the cell wall fraction, with and without adsorbed $\operatorname{SlpA} A_{27-235}$, was performed as described previously (Lemaire et al., 1995).

\section{RESULTS}

\section{Identification of the S-layer protein of C. thermocellum}

Two major polypeptides with molecular masses of 50 and $140 \mathrm{kDa}$ co-sediment with cell envelopes of C. thermocellum. The $50 \mathrm{kDa}$ polypeptide was partially solubilized in the presence of $1 \mathrm{M} \mathrm{NaCl}$, and totally solubilized in the presence of $1 \%$ Triton X-100, leaving the $140 \mathrm{kDa}$ polypeptide, which was insoluble in the presence of Triton X-100. Both proteins were extracted 


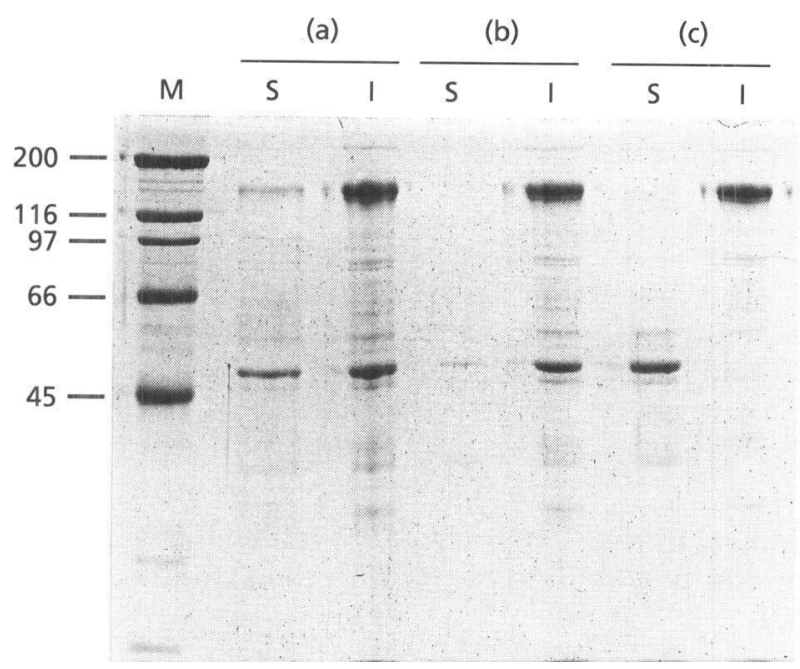

Fig. 1. SDS-PAGE analysis of $C$. thermocellum cell envelopes. Cell envelopes were prepared as described in Methods and washed successively with $1 \mathrm{M} \mathrm{NaCl}$ (a), $50 \mathrm{mM}$ Tris/ $\mathrm{HCl}(\mathrm{pH} 7.5)$ containing $150 \mathrm{mM} \mathrm{NaCl}$ (b) and $50 \mathrm{mM}$ Tris/ $\mathrm{HCl}$ (pH 7.5) containing $150 \mathrm{mM} \mathrm{NaCl}$ and $1 \%$ Triton $X-100$ (c). Aliquots equivalent to $100 \mu \mathrm{l}$ original culture from the soluble (S) and insoluble (I) fraction obtained after each washing step were analysed by SDS-PAGE (Laemmli, 1970). The size in kDa of molecular mass markers $(M)$ is indicated on the left.

by hot SDS-PAGE sample buffer (Fig. 1). Electron microscopic examination of the preparation before (data not shown) and after (Fig. 2) Triton X-100 extraction showed the presence of cell envelope fragments displaying a regular, oblique arrangement of subunits, typical of S-layer lattices. The $140 \mathrm{kDa}$ polypeptide was by far the most abundant protein which could be solubilized by hot SDS from the Triton-X-100-extracted preparation. Since it is known from amino acid analysis that the insoluble cell wall fraction obtained after washing envelopes with hot SDS is devoid of associated protein (Lemaire et al., 1995), this suggests that the $140 \mathrm{kDa}$ polypeptide corresponds to the S-layer protomer.

\section{Association of the S-layer protein with the cell wall}

Fig. 3 shows that the $140 \mathrm{kDa}$ S-layer protein can be solubilized by incubating Triton-X-100-treated cell envelopes in the presence of lysozyme, indicating that it is probably associated, directly or indirectly, with the peptidoglycan layer. Little solubilization occurred upon incubating the preparation at $37^{\circ} \mathrm{C}$ for the same period of time in the absence of lysozyme, although upon longer incubation (several hours), the S-layer protein was ultimately released spontaneously in the supernatant (data not shown).

\section{Cloning and sequencing of the s/pA gene encoding the S-layer protein}

A $1.33 \mathrm{~kb}$ HindIII fragment of the slpA gene encoding the $\mathrm{S}$-layer protein was cloned by hybridization with a degenerate oligonucleotide probe derived from the

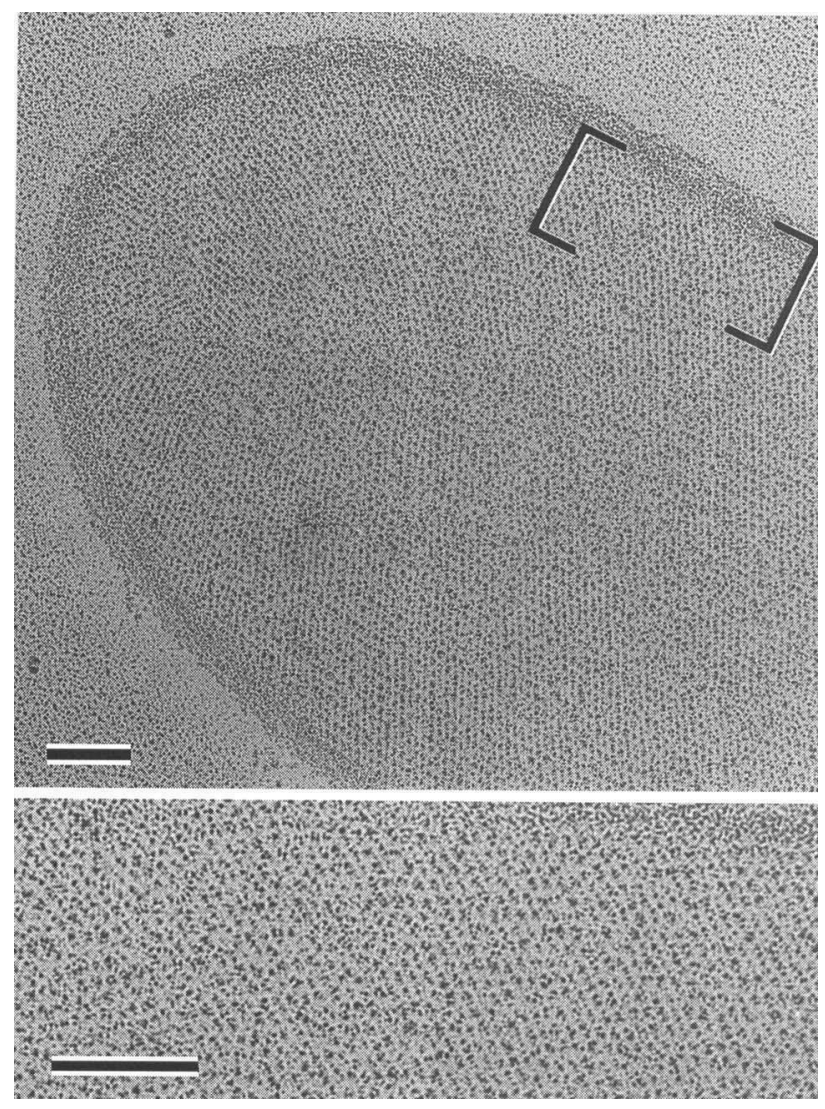

Fig. 2. Electron micrograph of a cell envelope fragment treated with Triton $\mathrm{X}-100$ and stained by rotary shadowing. The region shown in brackets in the top part of the figure is shown enlarged in the bottom part. Bar, $100 \mathrm{~nm}$.

sequence of an internal peptide of the protein. Fragments covering the rest of the gene were cloned by "chromosome walking' on either side of the cloned fragment. The nucleotide sequence shows the presence of an open reading frame encoding a polypeptide of 1036 residues, with a molecular mass of $113260 \mathrm{Da}$. The predicted amino acid sequence matches the sequence of the peptide used to design the oligonucleotide probe, as well as that of another internal peptide. The sequence encoding the amino-terminus of the protein isolated from C. thermocellum starts at the 27 th codon of the coding sequence. The composition of the mature protein is similar to the composition reported by Lamed \& Bayer (1988) for a $130 \mathrm{kDa}$ glycoprotein present in the culture supernatant and on the cell surface of C. thermocellum (Table 1 ).

\section{Motifs identified within the sequence of the SIpA polypeptide}

A summary of the features identified within the sequence of SlpA is presented in Fig. 4. SlpA shares a conserved core of about 450 residues with two other S-layer proteins, the outer wall protein of Bacillus brevis (GenBank accession no. P09333) (Tsuboi et al., 1986), and the S-layer protein of Bacillus sphaericus (GenBank accession no. P38537) (Bowditch et al., 1989). The three 
(a)

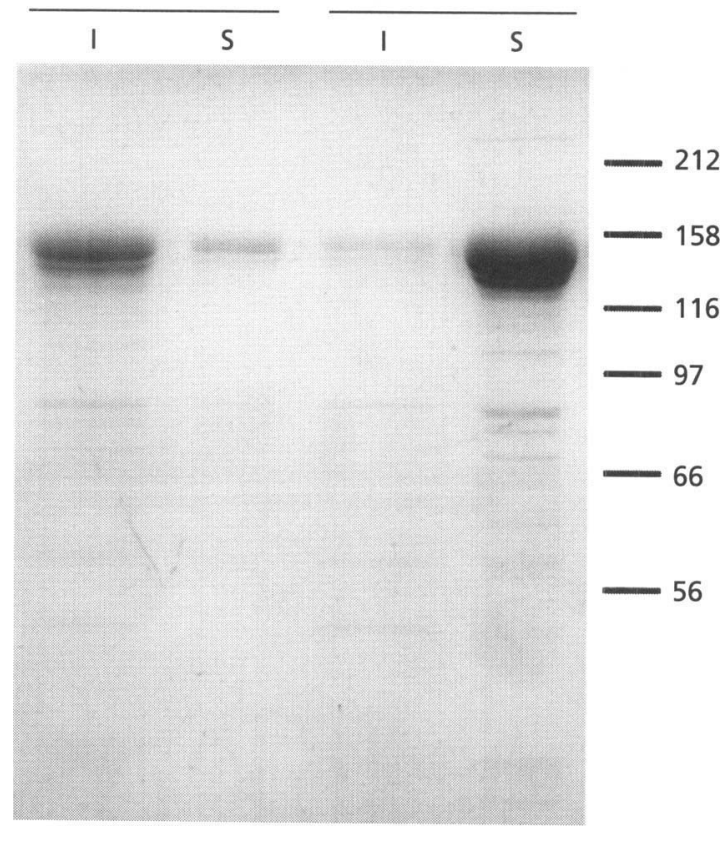

Fig. 3. Solubilization of the S-layer protein upon lysozyme treatment of cell envelopes. Triton-X-100-treated cell envelopes were incubated in the presence or absence of lysozyme as described in Methods. The solubilized (S) and insoluble (I) fractions were analysed by SDS-PAGE after extraction of the latter with SDS-containing sample buffer. (a) Envelopes incubated without lysozyme; (b) envelopes incubated in the presence of lysozyme. The migration of molecular size markers (in $\mathrm{kDa}$ ) is indicated on the right.

Table 1. Amino acid composition of SIpA and of the DE130 glycoconjugate analysed by Lamed \& Bayer (1988)

The amino acid composition is expressed as residues $/ 100$ residues. ND, Not determined.

\begin{tabular}{|lrr|}
\hline Amino acid & SlpA $^{*}$ & DE-130 \\
\hline Asx & $13 \cdot 37$ & $13 \cdot 6$ \\
Thr & $8 \cdot 22$ & $7 \cdot 7$ \\
Ser & $5 \cdot 84$ & $5 \cdot 8$ \\
Glx & $11 \cdot 98$ & $13 \cdot 6$ \\
Pro & $2 \cdot 57$ & $2 \cdot 7$ \\
Gly & $6 \cdot 44$ & $6 \cdot 6$ \\
Ala & $8 \cdot 42$ & $8 \cdot 5$ \\
Cys & $0 \cdot 10$ & 0.0 \\
Val & $10 \cdot 59$ & $7 \cdot 8$ \\
Met & $0 \cdot 79$ & $1 \cdot 0$ \\
Ile & $5 \cdot 94$ & $4 \cdot 3$ \\
Leu & $6 \cdot 93$ & $6 \cdot 7$ \\
Tyr & $4 \cdot 36$ & $4 \cdot 8$ \\
Phe & $2 \cdot 97$ & $3 \cdot 2$ \\
His & $0 \cdot 00$ & 0.3 \\
Lys & $9 \cdot 41$ & $8 \cdot 6$ \\
Arg & $1 \cdot 68$ & $1 \cdot 7$ \\
Trp & $0 \cdot 40$ & ND \\
\hline
\end{tabular}

* As predicted from the sequence of the mature protein. sequences share a reiterated motif which is repeated five times in each polypeptide. The first four reiterations occur at intervals of about 100 residues, while the fifth one is located some 220 residues downstream from the fourth one. The amino-terminal region contains three segments resembling SLH domains. However, the similarity is not very strong. In particular, most other SLH segments contain the signature $(I, L, V, M, A)(T, S) R$ $(\mathrm{A}, \mathrm{S}, \mathrm{Q})(\mathbf{E}, \mathrm{D}, \mathrm{Q})$ (most frequently found residues are in bold) (Fig. 5 and Lupas et al., 1994), but this motif is absent from the second repeat of SlpA, and barely recognizable in the first and third repeats.

\section{Binding to the C. thermocellum cell wall of a 209- residue polypeptide comprising the SLH domain of SIpA}

By analogy with other SLH domains, it was surmised that the SLH-like segment of SlpA may mediate attachment of the S-layer to the cell wall. The SlpA $\mathrm{A}_{27-235}$ polypeptide, containing the SLH-like region, was constructed by fusing a 209-residue segment extending downstream from the amino-terminus of mature SlpA to the $\mathrm{His}_{6}$ tag encoded by the $\mathrm{pQE}-30$ expression vector (Fig. 4). After purification by $\mathrm{Ni}^{2+}$ affinity chromatography, SlpA $A_{27-235}$ was tested for its capacity to bind to the SDS-extracted cell wall fraction from C. thermocellum. As shown in Fig. 6, $\operatorname{Slp} \mathrm{A}_{27-235}$ was able to bind to the cell wall fraction. Little if any Slp $\mathrm{A}_{27-235}$ was released upon washing the cell wall pellet. No SlpA $\mathrm{p}_{27-235}$ was pelleted in the absence of the cell wall fraction (data not shown). To show that the interaction between $\operatorname{SlpA}_{27-235}$ and the cell wall fraction was specific, the experiment was repeated with a mixture containing a fourfold excess of a crude cytoplasmic extract of $E$. coli proteins added to $S l p A_{27-235}$. Although some $E$. coli polypeptides marginally adsorbed to the cell wall fraction, SlpA $\mathrm{A}_{27-235}$ was by far the major polypeptide co-sedimenting with the cell wall pellet (Fig. 6). To estimate the amount of bound SlpA $\mathrm{A}_{27-235}$, amino acid analysis was performed on the purified polypeptide and on the cell wall fraction containing or not containing the co-adsorbed polypeptide. Based on the glucosamine and phenylalanine content of the samples, $0.066 \mathrm{~mol} \mathrm{SlpA_{27-235 }}$ was bound per mol glucosamine plus muramic acid present in the pelleted fraction (muramic acid is converted into glucosamine during the acid hydrolysis performed prior to amino acid analysis).

\section{DISCUSSION}

The C. thermocellum cell envelope contains two major components, with molecular masses of about 50 and $140 \mathrm{kDa}$. The $50 \mathrm{kDa}$ component can be solubilized in the presence of Triton X-100, suggesting that it may be included within the cytoplasmic membrane. The $140 \mathrm{kDa}$ protein, now termed SlpA, is the protomer forming the S-layer surrounding the cell. SlpA is released in large quantities into the medium of cultures grown to stationary phase (unpublished observations) and appears to be identical to DE-130, the major non- 

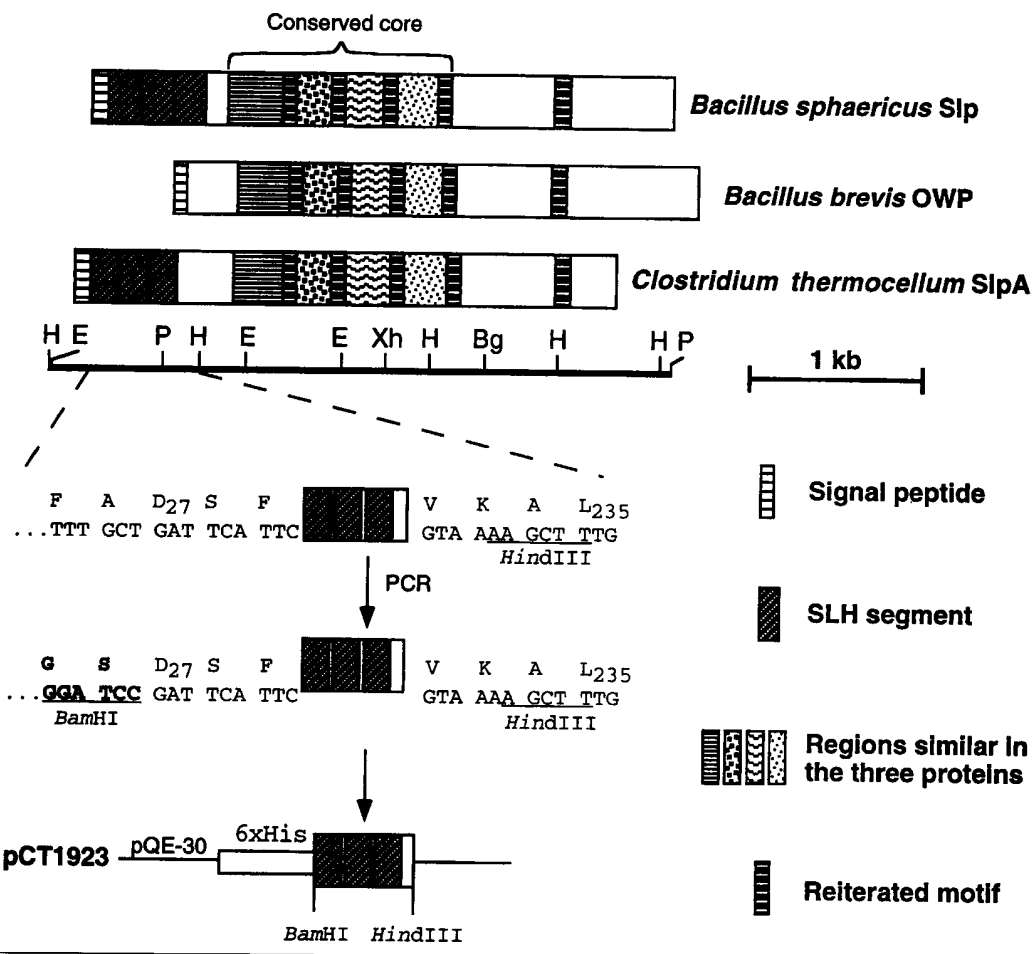

Fig. 4. Map of the s/pA region of $C$. thermocellum and construction of pCT1923 encoding residues $27-235$ of SIpA fused to six $H$ is residues. The positions of the segments encoding the various regions identified within SIpA are indicated by boxes of different patterns, together with similar regions found in $B$. brevis outer wall protein (OWP) and B. sphaericus S-layer protein (SIp). Residues of $\operatorname{sipA}$ that have been modified to introduce a $B a m H I$ site are shown in bold type. Bg, Bg/II; H, HindIII; E, ECoRl; P, Pstl; Xh, Xhol.

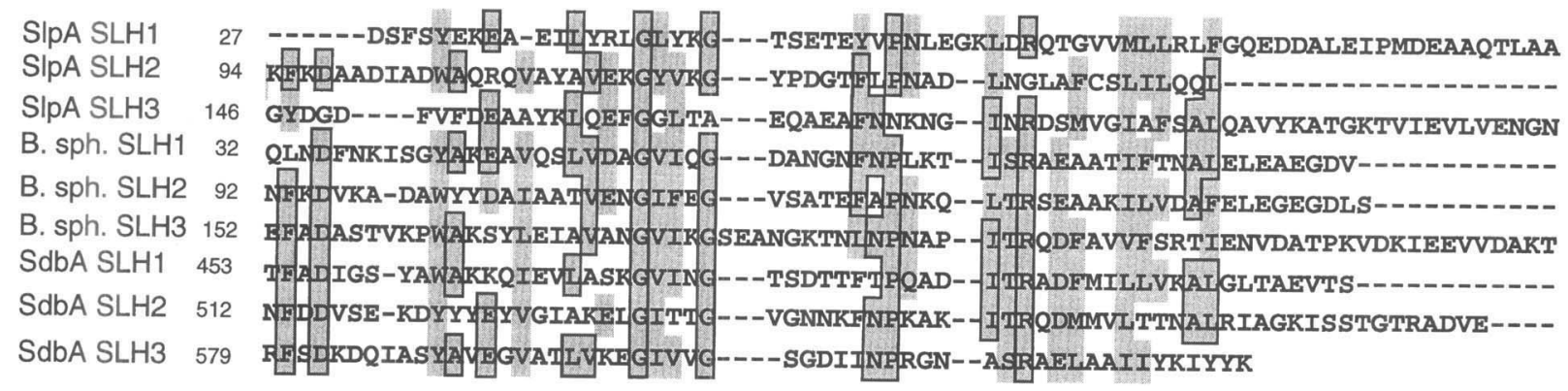

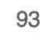

145

213

91

151

225

511

578

631

Fig. 5. Alignment of the SLH segments of $C$. thermocellum SIpA (SIpA SLH1, SLH2 and SLH3) with the three SLH segments of the $B$. sphaericus S-layer protein (B. sph. SLH1, SLH2 and SLH3) and with the three SLH segments of C. thermocellum SdbA (SdbA SLH1, SLH2 and SLH3) (Leibovitz \& Béguin, 1996) (GenBank accession no. U49980). Boxes and shading indicate residues that are identical or similar in the majority of the segments, respectively.

cellulosomal protein identified in culture supernatants of C. thermocellum YS (Lamed \& Bayer, 1988). Although the DE-130 component was not identified as an S-layer protein, its amino acid composition closely matched that predicted for SlpA, and antibody staining showed that it was indeed localized on the surface of $C$. thermocellum (Lamed \& Bayer, 1988). DE-130 contains about $10 \%$ O-linked carbohydrate. However, the carbohydrate chains differ from those present in the cellulosome-integrating protein CipA (formerly $S_{L}$ or S1), since, unlike CipA, DE-130 does not bind to Griffonia simplicifolia lectin (Lamed \& Bayer, 1988). The presence of carbohydrate may explain why SlpA/DE-130 migrates slower in SDS-PAGE than expected from the molecular mass of $110513 \mathrm{Da}$ predicted from the sequence of the $\operatorname{sl} A A$ gene. In addition to contributing to the mass of glycoproteins, glycosylation is known to result in anomalous retardation in SDS-PAGE, due to reduced binding of SDS.

C. thermocellum SlpA, the outer wall protein of $B$. brevis and the S-layer protein of B. sphaericus form a family of S-layer proteins with a related core. The core sequence is punctuated by reiterated motifs. Speculations about the role of these motifs are premature, but it is tempting to correlate their presence at regular intervals with the structural constraints deriving from the formation of a regular lattice. The spacing between the fourth and the fifth repeat is nearly twice that observed between the other repeats, as if one repeat had been lost or altered beyond recognition in the course of evolution.

Maintenance of the S-layer of C. thermocellum depends on the integrity of the underlying peptidoglycan. This 


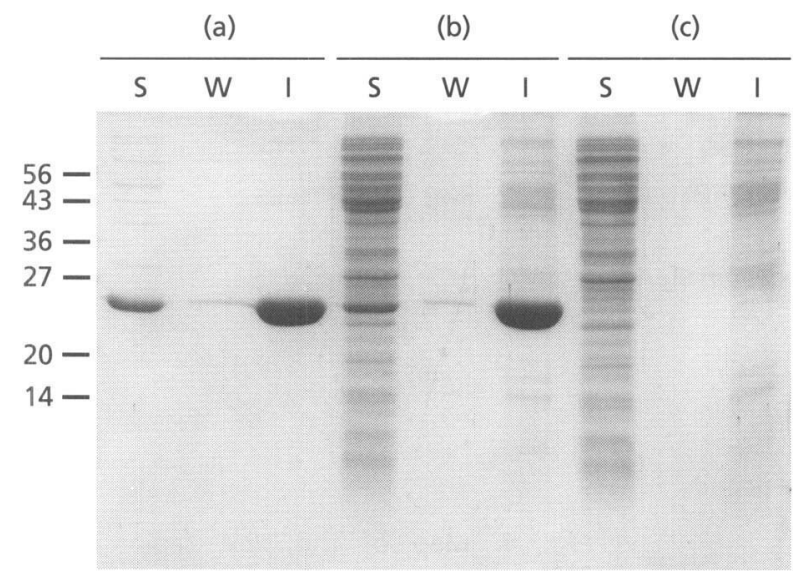

Fig. 6. Binding of the $S_{1 p A_{27-235}}$ polypeptide to the cell wall fraction of $C$. thermocellum. (a) SDS-extracted cell wall fraction C4 $(0.3 \mathrm{ml})$ (Lemaire et al., 1995), corresponding to $15 \mathrm{ml}$ original mid-exponential-phase culture of $C$. thermocellum, and

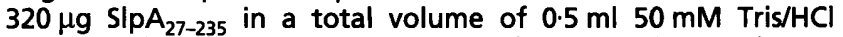
(pH 7.5). (b) As (a), plus $1.2 \mathrm{mg}$ protein from a crude cytoplasmic extract of $E$. coli TG1. (c) Cell wall fraction plus cytoplasmic extract alone. All mixtures in $(a-c)$ were incubated for $4 \mathrm{~h}$ at $37^{\circ} \mathrm{C}$ and centrifuged at $40000 \mathrm{~g}$ for $20 \mathrm{~min}$. The supernatant yielded fraction $S$ (soluble). Fraction $\mathbf{W}$ (wash) was obtained after washing the pellet in $0.5 \mathrm{ml}$ of the same buffer. The washed pellet was extracted with $50 \mu \mathrm{l}$ sample buffer, yielding fraction I (insoluble); $5 \mu$ l of each sample was analysed by SDSPAGE.

indicates that SlpA must interact non-covalently with the cell wall. The amino-terminal region of SlpA was able to bind independently to hot-SDS-extracted cell envelopes of $C$. thermocellum. Thus, we suggest that this region participates in anchoring the S-layer to the cell wall. Sequence comparison shows that it is distantly related to previously identified SLH domains. These domains, which are present in numerous bacterial exoproteins, have been shown to bind in vitro (Lemaire et al., 1995) and in vivo (Olabarría et al., 1996) to bacterial cell walls. By cell wall, we mean peptidoglycan and non-protein polymers that may be associated with it (Doyle, 1992), since experiments reported in this paper or in the above references do not discriminate between the two. Indeed, it is debated whether cell-wall-associated S-layer proteins attach to peptidoglycan, as proposed by Lupas et al. (1994), or to a peptidoglycanassociated polysaccharide, possibly containing glucosamine or $\mathrm{N}$-acetylglucosamine (Hastie \& Brinton, 1979; Sára et al., 1996).

In spite of similarities, the sequence and the properties of the amino-terminal region of SlpA differ significantly from those of the more canonical SLH domains, such as those found in several proteins of C. thermocellum, e.g. $\mathrm{OlpB}$, which are involved in attachment of cellulosomes or individual cellulases to the cell surface (Fujino et al., 1993; Leibovitz \& Béguin, 1996; Salamitou et al., $1994 a, b)$. Sequence differences are reflected in differences in immunological and biochemical properties between OlpB and SlpA. Antibodies directed against the
SLH segments present at the carboxy-terminus of OlpB cross-react with SLH segments present in three other polypeptides, but not with SlpA (Lemaire et al., 1995). In addition, the SLH segments of OlpB not only bind to the cell surface of $C$. thermocellum, but also interact in vitro with SLH domains borne by other proteins (Lemaire et al., 1995). In contrast, the SLH repeats of OlpB do not bind to SlpA (Lemaire et al., 1995). Once structural data become available, it will be interesting to see whether binding of SLH domains to the cell wall involves residues that are conserved in SlpA and, conversely, whether homologous SLH-SLH interaction depends on residues that are absent from SlpA.

\section{ACKNOWLEDGEMENTS}

We wish to thank J. d'Alayer for sequencing the aminoterminus and internal peptides of SlpA, and F. Baleux for performing the amino acid analysis and quantification of $\mathrm{SlpA}_{27-235}$ bound to the cell wall. We are grateful to J.-P. Aubert and M. Schwartz for their continuing interest and support.

M.L. was the recipient of a fellowship from the Ministère de l'Enseignement Supérieur et de la Recherche. This work was supported by contract AIR1-CT-0321 from the European Commission.

\section{REFERENCES}

Ausubel, F. M., Brent, R., Kingston, R. E., Moore, D. D., Seidman, J. G., Smith, J. A. \& Struhl, K. (1990). Current Protocols in Molecular Biology. New York: Greene Publishing and Wiley Interscience.

Baccalà, R., Guilbert, B., Labrousse, H., Avrameas, S. \& Gounon, P. (1991). Visualization of natural autoantibody polyreactivity by rotary metal-shadowing electron microscopy. Res Immunol 142, 299-312.

Bayer, E. A. \& Lamed, R. (1986). Ultrastructure of the cell surface cellulosome of Clostridium thermocellum and its interaction with cellulose. J Bacteriol 167, 828-836.

Bayer, E. A., Setter, E. \& Lamed, R. (1985). Organization and distribution of the cellulosome in Clostridium thermocellum. $J$ Bacteriol 163, 552-559.

Bowditch, R. D., Baumann, P. \& Yousten, A. A. (1989). Cloning and sequencing of the gene encoding a 125-kilodalton surfacelayer protein from Bacillus sphaericus 2362 and a related cryptic gene. J Bacteriol 171, 4178-4188.

Doyle, R. J. (1992). Cell walls of bacteria. In Encyclopedia of Microbiology, pp. 479-493. Edited by J. Lederberg. New York: Academic Press.

Farabaugh, P. J. (1978). Sequence of the lacI gene. Nature 274, 765-769.

Fujino, T., Béguin, P. \& Aubert, J.-P. (1993). Organization of a Clostridium thermocellum gene cluster encoding the cellulosomal scaffolding protein CipA and a protein possibly involved in the attachment of the cellulosome to the cell surface. J Bacteriol 175, 1891-1899.

Gibson, T. J. (1984). Studies on the Epstein-Barr virus genome. $\mathrm{PhD}$ thesis, University of Cambridge.

Hastie, A. T. \& Brinton, C. C., Jr (1979). Specific interaction of the tetragonally arrayed protein layer of Bacillus sphaericus with its peptidoglycan sacculus. J Bacteriol 138, 1010-1021. 
Janknecht, R., de Martynoff, G., Lou, J., Hipskind, R. A., Nordheim, A. \& Stunnenberg, H. G. (1991). Rapid and efficient purification of native histidine-tagged protein expressed by recombinant vaccinia virus. Proc Natl Acad Sci USA 88, 8972-8976.

Johnson, E. A., Sakajoh, M., Halliwell, G., Madia, A. \& Demain, A. L. (1982). Saccharification of complex cellulosic substrates by the cellulase system from Clostridium thermocellum. Appl Environ Microbiol 43, 1125-1132.

Laemmli, U. K. (1970). Cleavage of structural proteins during the assembly of the head of bacteriophage T4. Nature 227, 680-685.

Lamed, R. \& Bayer, E. A. (1988). The cellulosome concept: exocellular/extracellular enzyme reactor centers for efficient binding and cellulolysis. In Biochemistry and Genetics of Cellulose Degradation (FEMS Symposium no. 43), pp. 101-116. Edited by J.-P. Aubert, P. Béguin \& J. Millet. London \& New York: Academic Press.

Lamed, R., Setter, E., Kenig, R. \& Bayer, E. A. (1983). The cellulosome: a discrete cell surface organelle of Clostridium thermocellum which exhibits separate antigenic, cellulose-binding and various cellulolytic activities. Biotechnol Bioeng Symp 13, 163-181.

Leibovitz, E. \& Béguin, P. (1996). A new type of cohesin domain that specifically binds the dockerin domain of the Clostridium thermocellum cellulosome-integrating protein CipA. J Bacteriol 178, 3077-3084.

Lemaire, M., Ohayon, H., Gounon, P., Fujino, T. \& Béguin, P. (1995). OlpB, a new outer layer protein of Clostridium thermocellum, and binding of its S-layer-like domain to components of the cell envelope. J Bacteriol 177, 2451-2459.

Lupas, A., Engelhardt, H., Peters, J., Santarius, U., Volker, S. \& Baumeister, W. (1994). Domain structure of the Acetogenium kivui surface layer revealed by electron crystallography and sequence analysis. J Bacteriol 176, 1224-1233.

Maniatis, T., Fritsch, E. F. \& Sambrook, J. (1982). Molecular Cloning: a Laboratory Manual. Cold Spring Harbor, NY: Cold Spring Harbor Laboratory.

Matuschek, M., Burchhardt, G., Sahm, K. \& Bahl, H. (1994). Pullulanase of Thermoanaerobacter thermosulfurigenes EM1 (Clostridium thermosulfurogenes): molecular analysis of the gene, composite structure of the enzyme, and a common model for its attachment to the cell surface. J Bacteriol 176, 3295-3302. Nolte, A. (1992). Ultrastrukturelle, enzymkinetische und immuno- cytochemishe Untersuchungen der extrazellulären Cellulase von Clostridium thermocellum JW20. PhD thesis, Georg-AugustUniversität Göttingen.

Nolte, A. \& Mayer, F. (1989). Localization and immunological characterization of the cellulolytic enzyme system in Clostridium thermocellum. FEMS Microbiol Lett 61, 65-72.

Olabarría, G., Carrascosa, J. L., de Pedro, M. A. \& Berenguer, J. (1996). A conserved motif in S-layer proteins is involved in peptidoglycan binding in Thermus thermophilus. J Bacteriol 178, 4765-4772.

Quiviger, B., Franche, C., Lutfalla, G. D. R., Haselkorn, R. \& Elmerich, C. (1982). Cloning of a nitrogen fixation (nif) gene cluster of Azospirillum brasilense. Biochimie 64, 495-502.

Salamitou, S., Lemaire, M., Fujino, T., Ohayon, H., Gounon, P., Béguin, P. \& Aubert, J.-P. (1994a). Subcellular localization of Clostridium thermocellum ORF3p, a protein carrying a receptor for the docking sequence borne by the catalytic components of the cellulosome. J Bacteriol 176, 2828-2834.

Salamitou, S., Raynaud, O., Lemaire, M., Coughlan, M., Béguin, P. \& Aubert, J.-P. (1994b). Recognition specificity of the duplicated segments present in Clostridium thermocellum endoglucanase CelD and in the cellulosome-integrating protein CipA. J Bacteriol 176, 2822-2827.

Sára, M., Kuen, B., Mayer, H. F., Mandl, F., Schuster, K. C. \& Sleytr, U. B. (1996). Dynamics in oxygen-induced changes in S-layer protein synthesis from Bacillus stearothermophilus PV72 and the S-layer-deficient variant T5 in continuous culture and studies of the cell wall composition. J Bacteriol 178, 2108-2117.

Tailliez, P., Girard, H., Millet, J. \& Béguin, P. (1989). Enhanced cellulose fermentation by an asporogenous and ethanol-tolerant mutant of Clostridium thermocellum. Appl Environ Microbiol 55, 207-211.

Tsuboi, A., Uchihi, R., Tabata, R., Takahashi, Y., Hashiba, H., Sasaki, T., Yamagata, H., Tsukagoshi, N. \& Udaka, S. (1986). Characterization of the genes coding for two major cell wall proteins from protein-producing Bacillus brevis 47: complete nucleotide sequence of the outer wall protein gene. J Bacteriol 168, 365-373.

Villarejo, M. R. \& Zabin, I. (1974). $\beta$-Galactosidase from termination and deletion mutant strains. J Bacteriol 120, 466-474.

Received 10 March 1997; revised 19 June 1997; accepted 11 September 1997. 